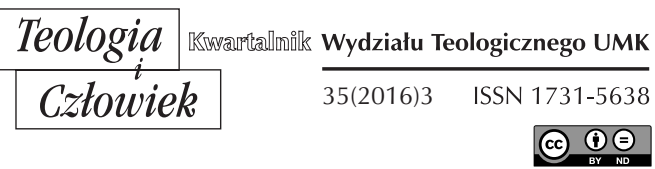

KS. ADAM JÓZEF SOBCZYK MSF*

TORUŃ

\title{
KONCEPCJA DUCHOWOŚCl MAŁŻEŃSTWA I RODZINY W ŚWIETLE ADHORTACJI AMORIS LAETITIA
}

DOI: http://dx.doi.org/10.12775/TiCz.2016.036

W kwietniu 2016 roku ukazał się długo oczekiwany dokument będący owocem dwóch synodów biskupów poświęconych tematowi małżeństwa i rodziny. Adhortacja posynodalna Amoris Laetitia składa się z dziewięciu rozdziałów obejmujących rozmaite aspekty życia małżeństwa i rodziny. Jeden z nich, co należy podkreślić, w całości poświęcony został duchowości małżeństwa i rodziny, choć temat duchowości przejawia się także w pozostałych częściach dokumentu. Podkreślenie przez Papieża znaczenia duchowości małżeńskiej i rodzinnej w codzienności życia stanowi wystarczające uzasadnienie do dokonania analizy dokumentu pod tym kątem, a następnie syntezy zebranego materiału, prowadzącej do

* Dr hab. Adam Józef Sobczyk - kapłan ze Zgromadzenia Misjonarzy Świętej Rodziny. Od 2011 roku członek zwyczajny Polskiego Stowarzyszenia Teologów Duchowości. Wykładowca teologii duchowości, kierownictwa duchowego i poradnictwa rodzin; rekolekcjonista. Autor kilkunastu książek i kilkudziesięciu artykułów naukowych i popularnonaukowych z dziedziny historii i teologii duchowości ze szczególnym uwzględnieniem duchowości zakonnej oraz duchowości małżeńskiej i rodzinnej (ajsobczyk72@ gmail.com). 
nakreślenia pewnej koncepcji, zaproponowanej przez Papieża Franciszka, duchowości tej wspólnoty życia i miłości. Propozycja ta stanowi z jednej strony owoc pracy synodów, a z drugiej najnowsze wytyczne odnośnie do życia duchowego małżeństw i rodzin w pierwszej połowie XXI wieku.

\section{BIBLIJNE ŹRÓDŁA DUCHOWOŚCl MAŁŻEŃSKIEJ I RODZINNEJ}

Analizę koncepcji duchowości małżeńskiej i rodzinnej proponowanej przez Papieża Franciszka należy rozpocząć od przedstawienia jej biblijnych podstaw. Ojciec Święty ukazuje powołanie do małżeństwa w oparciu o wydarzenie stworzenia pierwszych rodziców. Zauważa, że Biblia jest pełna rodzin i związanych $\mathrm{z}$ tą instytucją wydarzeń ${ }^{1}$. Z opisem $\mathrm{z}$ księgi Rodzaju $(2,24)$ zestawia słowa Chrystusa z Ewangelii Mateusza $(19,4 \mathrm{n})$. Zabieg ten pozwala mu na pokazanie pary ludzkiej w jej fundamentalnej rzeczywistości męża i żony oraz założycieli rodziny. Zdaniem Franciszka komunia miłości mężczyzny i kobiety, realizująca się we wszystkich wymiarach ich egzystencji, stanowi doskonałą paralelą przybliżającą obraz Boga. Natomiast płodność małżonków jako wyraz ich wzajemnej miłości staje się widzialnym znakiem aktu stwórczego Boga ${ }^{2}$.

Papież Franciszek zauważa, że w podanym wyżej fragmencie Jezus podkreśla godność pary małżeńskiej poprzez nawiązanie do kategorii daru ukazującej powołanie kobiety jako odpowiedniej osoby i towarzyszki życia dla mężczyzny. Cytując Księgę Rodzaju: „złączy się ze swoją żoną, i będą oboje jednym ciałem" (Mt 19,5; por. Rdz 2,24), Papież wyjaśnia czasownik „złączyć się", który w oryginale hebrajskim oznacza ścisłe współbrzmienie, przylgnięcie fizyczne i wewnętrzne, aż po punkt, który jest używany do opisania zjednoczenia z Bogiem: „do Ciebie lgnie moja dusza” (Ps 63,9). $\mathrm{W}$ ten sposób przywołuje się zjednoczenie małżeńskie nie tylko $\mathrm{w}$ jego wymiarze seksualnym i cielesnym, ale również w jego dobrowolnym obdarowaniu miłością. Owocem tego związku jest to, że: „stają się jednym ciałem" - czy to w uścisku fizycznym, czy też w jedności serc i życia³.

\footnotetext{
${ }^{1}$ Por. Franciszek, Adhortacja, Amoris Laetitia (dalej AL) 8.

2 Por. tamże, 9-10.

3 Tamże, 12-13.
} 
Para, która kocha i rodzi życie, stanowi figurę zdolną ukazać Boga jako Stwórcę i Zbawiciela. Według Papieża w świetle relacji małżonków znajduje się możliwość odkrycia i opisania tajemnicy Boga kontemplowanej przez chrześcijan w Trójcy Świętej. W tej tajemnicy chrześcijanin poznaje Boga Ojca, Syna i Ducha Miłości. Trójjedyny Bóg jest komunią miłości, a rodzina jest jej żyjącym odzwierciedleniem. Papież nawiązuje tutaj do nauczania Jana Pawła II, umiejscawiającego miłość małżeńską $\mathrm{w}$ kategorii wzajemnego daru z siebie tworzącego comunnio personarum i communio amoris . $^{4}$.

Franciszek w całym dokumencie w wielu miejscach nawiązuje do trynitarnego wymiaru duchowości małżeńskiej i rodzinnej. Zauważa, że trynitarny aspekt małżeństwa przybiera nową postać w teologii Pawłowej, gdzie jest związany z tajemnicą zjednoczenia między Chrystusem a Kościołem (por. Ef 5,21-33) .

Owocem jedności i miłości małżeńskiej jest dziecko. Ojciec Święty przytacza Psalm 127, w którym autor wychwala dar dzieci przy użyciu obrazów, jakie odnoszą się do budowy domu bądź do życia społecznego i handlowego, jakie toczyło się w bramie miasta: „Oto synowie są darem Pana, a owoc łona nagrodą"6.

Zaznacza jednak wolność dziecka, które nie może stać się niewolnikiem rodziny. Każdy człowiek ma przed sobą swoją własną drogę życiową i powołanie, które powinien odczytać i w wolności sumienia zrealizować. Wprawdzie Jezus stanowi wzór posłuszeństwa wobec rodziców, podporządkowując się im (por. Łk 2,51), jednak w swoich wypowiedziach przypomina Maryi i Józefowi, że wybór życiowy dziecka i jego własne

4 Por. K. Wojtyła, Rodzina jako communio personarum. Próba interpretacji teologicznej, „Ateneum Kapłańskie” 66 (1974), s. 347-361; tenże, Rodzicielstwo a communio personarum. Małżeństwo a rodzicielstwo, AK 67 (1975), s. 17-31; tenże, Propedeutyka sakramentu małżeństwa, „Ateneum Kapłańskie” 50 (1958), s. 20-33. Do tej tematyki kardynał K. Wojtyła powrócił już jako papież: Mężczyzna i niewiasta stworzył ich, (Rzym 1980), a rozwinął w adhortacji apostolskiej Familiaris Consortio, gdzie termin komunia został podany 48 razy, w tym 21 do małżeństwa, 27 do rodziny a 3 do obydwu. Papież ponadto 15 razy wykorzystuje to określenie w odniesieniu do Boga, Kościoła i Eucharystii. Temat ten podjął również w Liście do rodzin Gratissimam sane, (Rzym 1994); AL 11.

${ }^{5}$ Por. AL, 12; Franciszek, Dwoje w jednym. Audiencja generalna z 2.04.2014, „L ' Osservatore Romano” wersja polska 35 (2014), nr 5, s. 37.

${ }^{6}$ Por. AL 14. 
powołanie chrześcijańskie mogą wymagać oddzielenia od rodziców, aby podążać swoją własną drogą do królestwa Bożego (por. Mt 10,34-37; Łk 9,59-62) ${ }^{7}$.

Rozpatrując eklezjalny wymiar duchowości rodziny, Papież nawiązuje do Nowego Testamentu, gdzie mowa jest o „Kościele zbierającym się w domu" (por. 1 Kor 16,19; Rz 16,5; Kol 4,15; Flm 2). W oparciu o ten tekst sugeruje, że przestrzeń życiowa rodziny powinna zostać przekształcona w Kościół domowy, w miejsce sprawowania Eucharystii, obecności Chrystusa, co zapewni domownikom Boże błogosławieństwo (por. Ps 128,4-5). W tym domowym Kościele istotną rolę odgrywa formacja religijna. Papież, korzystając ze źródeł biblijnych, przedstawia rodzinę jako miejsce katechezy dzieci. Zwraca uwagę na sposób celebracji paschalnej (por. Wj 12,26-27; Pwt 6,20-25). Odnosi się również do żydowskiej hagady i dialogicznej narracji, która towarzyszy obrzędowi wieczerzy paschalnej (Ps 78,3-6). Podkreśla, że rodzina jest miejscem, gdzie rodzice stają się dla swoich dzieci pierwszymi nauczycielami wiary ${ }^{8}$.

Zadanie edukacji religijnej Papież powierza przede wszystkim rodzicom. Cytuje w tym miejscu liczne teksty z księgi Przysłów (por. 3,11-12; 6,20-22; 13,1; 22,15; 23,13-14; 29,17). Z kolei na dzieci kładzie obowiązek przyjęcia i praktykowania przykazania posłuszeństwa i miłości względem rodziców (por. Wj 20,12) ${ }^{9}$. Dodaje, że działalność wychowawcza - podobnie jak przekazywanie życia - jest odbiciem stwórczego dzieła Ojca ${ }^{10}$.

Uczestnictwo w stwórczym dziele Boga stanowi doskonały sposób umocnienia więzi rodzinnych. Większa relacja z Bogiem staje się podstawą głębszej więzi ze sobą poszczególnych ludzi. Pozwala to na dostrzeżenie nie tylko człowieka, ale na spojrzenie na człowieka oczami Boga. Kreuje również okazję do umacniania więzi w relacjach rodzinnych (por. Łk 8,21). Dokonuje się to miedzy innymi przez czułość. Papież po-

7 Por. tamże, 18.

8 Tamże, 15-16; Franciszek, Encyklika, Lumen fidei, nr 52-54; A. Sobczyk. Rodzina chrześcijańska w nauczaniu papieża Franciszka, „Teologia i moralność” 16 (2014) 2, s. 203-204.

${ }^{9}$ Por. AL 17; Franciszek, Każdego dnia odbudowujmy pokój w rodzinie. Rozważanie Papieża podczas spotkania modlitewnego z rodzinami z 26 X 2013, „L 'Osservatore Romano” wersja polska 34 (2013), nr 12, s. 11-12.

${ }^{10}$ Por. AL 29. 
twierdza to stwierdzenie w oparciu o Psalm 131 (por. Wj 4,22; Iz 49,15; Ps 27,10). Zaznacza, że więź miłości między wiernym a jego Panem wyraża się w rysach miłości rodzicielskiej lub matczynej. Można ją porównać do delikatnej i czułej intymności między matką a dzieckiem ${ }^{11}$.

Franciszek, analizując biblijne podstawy duchowości małżeńskiej i rodzinnej, zwraca uwagę na znaczenie duchowości codzienności życia. Z jednej strony nie ukrywa, że Pismo Święte przedstawia także smutną rzeczywistość bólu, zdrady i zła niszczącego rodzinę i jej intymną więź jako wspólnoty życia i miłości. Zaznacza, że życie rodzinne bywa dotknięte nierzadko drogą cierpienia, niezgody, a nawet sporów, tak, jak to miało miejsce między członkami rodzin patriarchów: Abrahama, Izaaka, Jakuba, Dawida i Hioba (Hi 19,13-14.17) ${ }^{12}$.

Z drugiej strony zauważa jednak, że sam Jezus urodził się w skromnej, niepozbawionej trudów i niebezpieczeństw rodzinie, której nie były obce: ubóstwo, brak domu czy ucieczka do obcej ziemi. Ponadto przedstawia Jezusa jako czułego na losy rodziny. Przypomina, że Syn Boży spotykał i leczył chorych (por. Mk 1,30-31), wskrzeszał zmarłych (por. Mk 5,22-24.35-43; J 11,1-44), (por. Łk 7,11-15), nawracał ze złej drogi celników (por. Mt 9,9-13; Łk 19,1-10) i grzeszników (por. Łk 7,36-50), pomógł rodzinie będącej w niezręcznej sytuacji w trakcie wesela w Kanie Galilejskiej (por. J 2,1-10) ${ }^{13}$.

Skuteczną pomoc rodzinie w trudnościach Papież widzi w lekturze Pisma Świętego, które jest dla niego źródłem duchowości rodzinnej. Ono wskazuje małżeństwu i rodzinie cel drogi, motywację do trwania i siłę do pokonywania przeciwności. Ono przedstawia Boga jako wrażliwego na ludzką niedolę (Ap 21,4) ${ }^{14}$.

Charakterystycznym elementem mającym olbrzymie znaczenie dla kształtowania duchowości małżeństwa i rodziny jest dla Franciszka praca.

${ }^{11}$ Por. tamże 28; Franciszek, $W$ rodzinie uczymy się kochać i bronić życia. Audiencja dla uczestników zgromadzenia plenarnego Papieskiej Rady ds. Rodziny z 25 X 2013, „L'Osservatore Romano” wersja polska 34 (2013), nr 12, s. 27.

12 Por. AL 19-20; EG 3; A. Sobczyk, Rodzina chrześcijańska w nauczaniu papieża Franciszka, s. 211.

${ }_{13}$ Por. AL 21.

${ }_{14}$ Por. tamże, 22; EG 262; A. Sobczyk, Rodzina chrześcijańska w nauczaniu papieża Franciszka, s. 211. 
Papież zwraca uwagę na jej biblijne fundamenty. Widzi pracę jako zasadniczy element godności życia ludzkiego (Rdz 2,15). Dzięki niej człowiek staje się Bożym pracownikiem, który przekształca materię i wykorzystuje siły stworzenia, wytwarzając „chleb zapracowany ciężko” (Ps 127,2), a także udoskonalając siebie samego. Zauważa, że w Psalmie 128, ukazany jest ojciec jako pracownik, który dziełem swoich rąk może podtrzymywać dobrobyt fizyczny i pogodę ducha swej rodziny: „z pracy rąk swoich będziesz pożywał, będziesz szczęśliwy i dobrze ci będzie" (Ps 128,2) ${ }^{15}$.

Praca w Piśmie świętym ma również znaczenie społeczne. Wpływa na spokój związany z przeświadczeniem o utrzymaniu rodziny a także jej stabilności i płodności (Ps 128,5-6). Papież wskazuje na fragmenty biblijne dotyczące podziału ról dla poszczególnych członków rodziny (por. Prz 31,10-31; Dz 18,3; 1 Kor 4,12; 9,12; 2 Tes 3,10). Podkreśla, że brak pracy i niepewność jutra stają się dla wielu ludzi cierpieniem, a brak źródeł codziennej egzystencji staje się przyczyną utraty pokój ducha i nierzadko więzi rodzinnych ${ }^{16}$.

\section{WZAJEMNY DAR MIŁOŚCI JAKO ISTOTA DUCHOWOŚCl MAŁŻEŃSKIEJ}

Istotą duchowości małżeńskiej i rodzinnej jest dla papieża Franciszka dar miłości z siebie dla innych (por. Mt 22,39; J 13,34). Miłość jest elementem wiążącym całej adhortacji. Papież poświeca jej wiele miejsca i ujmuje całą prawdę o rodzinie w aspekcie miłości, która powinna się rozwijać lub której zabrakło. Autentyczność miłości ożywiona jest codziennością. Opiera się na wielowymiarowej komunii. Według nauczania Papieża na podstawie daru wzajemnej miłości kształtowanej na wzór relacji trynitarnych można rozpatrywać duchowość komunii nadprzyrodzonej. Trójca Święta jest obecna w świątyni komunii małżeńskiej. Tak jak zamieszkuje w chwale swego ludu (por. Ps 22,4), tak też intymnie przebywa w miłości małżeńskiej, która oddaje chwałę $\mathrm{Bogu}^{17}$.

15 Por. AL 23.

16 Por. tamże, 24-25; Modlitwa papieża Franciszka do Świętej Rodziny, „L'Osservatore Romano” wersja polska 34 (2013), nr 12, s. 14.

17 Por. AL 27; 314. 
Papież wzywa członków rodziny do tego, by tworzyli komunię osób, która byłaby obrazem jedności między Ojcem, Synem i Duchem Świętym. Rodzina jest wezwana do wspólnej, codziennej modlitwy, czytania słowa Bożego i komunii eucharystycznej, aby rozwijać miłość i coraz bardziej stawać się świątynią, w której mieszka Duch Święty. Jako wzór komunii osób dla każdej rodziny Franciszek podaje Świętą Rodzinę z Nazaretu. Zachęca do kontemplacji życia ziemskiej trójcy zarówno w jej wzajemnych relacjach, jak i w wypełnianiu powierzonych im przez Boga obowiązków (por. Mt 2,11; Łk 2,19.51) ${ }^{18}$.

Tym bardziej, że na duchowość miłości rodzinnej składają się tysiące prawdziwych i konkretnych słów, spotkań i gestów. To one w swej różnorodności przyczyniają się do dojrzewania i umacniania jedności małżonków. Papież korzysta w tym miejscu z tekstu soborowego, mówiącego o wzajemnym oddaniu małżonków Bogu i sobie, co w konsekwencji umacnia miłość, bo łączy: „wartości ludzkie i Boskie”19. Z tego Franciszek wyprowadza wniosek, że duchowość małżeńska jest duchowością więzi, zamieszkałą przez Bożą miłośćco

Człowiek został powołany do życia w społeczeństwie, a podstawowym przejawem społecznego wymiaru osoby jest małżeństwo i rodzina ${ }^{21}$. Duchowość osoby ludzkiej realizuje się w danej wspólnocie rodzinnej. Dobrze przeżywana komunia rodzinna jest prawdziwą drogą do świętości w życiu codziennym i środkiem wewnętrznego zjednoczenia z Bogiem. Wspólnotowe zadania życia rodzinnego są okazją do coraz większego otwarcia serca, a to umożliwia coraz pełniejsze spotkanie z Panem (por. $1 \mathrm{~J} 4,12)^{22}$.

Sposobem zdobywania większej otwartości i umiejętności daru z siebie dla innych jest umocnienie i pogłębienie miłości małżeńskiej i rodzinnej. Łaska sakramentu małżeństwa ma w istocie przede wszystkim „udoskonalać miłość małżonków”23. Papież, nakazując wzrastać w miłości

${ }_{18}$ Por. tamże, 29-30.

19 Sobór Watykański II, Konstytucja duszpasterska o Kościele w świecie współczesnym, Gaudium et spes, (dalej KDK), nr 49.

20 Por. AL 315.

${ }^{21}$ Por. Jan Paweł II, Adhortacja, Christifideles laici (dalej CHL), nr 40.

22 Por. AL 316.

${ }^{23}$ Katechizm Kościoła Katolickiego (dalej KKK), nr 1641; AL 89-90. 
małżeńskiej, korzysta z tekstu „Hymnu do miłości” (1 Kor 13n) i wymienia cechy prawdziwej miłości² ${ }^{24}$ Wyjaśnia, że miłość, która jednoczy małżonków, uświęcona, ubogacona i oświecona łaską sakramentu małżeństwa, to „zjednoczenie woli”, duchowe i ofiarne, które jednak zawiera w sobie czułość przyjaźni i namiętność erotyczną, chociaż jest w stanie przetrwać nawet wtedy, gdy uczucia i namiętność ulegają osłabieniu ${ }^{25}$.

Małżeństwo według Franciszka jest ikoną miłości Boga do nas. Bóg tworzy z dwojga małżonków jedną egzystencję. Obdarza ich szczególną mocą, by wypełnili powierzoną im misję, aby mogli uwidaczniać pośród codzienności życia miłość, jaką Chrystus kocha swój Kościół. To stanowi, zdaniem Papieża, tajemnicę małżeństwa ${ }^{26}$.

Miłość małżeńska jest powołana do nieustannego dojrzewania. Wezwanie to pochodzi z pełnej komunii Trójcy Świętej, a także jedności między Chrystusem a Jego Kościołem ${ }^{27}$. W oparciu o nauczanie św. Tomasza Papież wyjaśnia, że miłości nic nie ogranicza, ponieważ jest ona udziałem w nieskończonej miłości, którą jest Duch Święty, a od strony podmiotu „za każdym razem, kiedy wzrasta miłość, tym bardziej wzrasta także zdolność do jeszcze większego jej rozwoju”28.

Z kolei sposobem, by żyć, rozwijać i wyrażać miłość w małżeństwie i życiu rodzinnym, jest dialog. Wymaga on długiej praktyki szukania czasu, cierpliwego i uważnego słuchania, aż druga osoba wyrazi wszystko, co chce wyrazić, i uszanowania osoby i jej zdania. Skuteczność dialogu zależy od bogactwa wewnętrznego rozmówców, co nakłada obowiązek odpowiedniej lektury, osobistej refleksji, modlitwy i otwartości na innych ${ }^{29}$.

Jednym z symptomów dojrzałej miłości małżeńskiej i rodzinnej, zdaniem Papieża, jest umiejętność doświadczania jej we wszystkich wy-

${ }^{24}$ Są nimi: cierpliwość, postawa życzliwości, uzdrowienie zazdrości, pokora, uprzejmość, hojność, wewnętrzny pokój, przebaczenie, radość z innymi, zaufanie, nadzieja, siła przetrzymania wszystkiego. AL 91-119.

${ }^{25}$ Por. Tomasz z Akwinu, Summa Theologiae I, q. 20, a. 1, ad 3; q. 27, a. 2; AL, 120 .

${ }^{26}$ Por. AL 124; Franciszek, Dwoje w jednym, Katecheza (2 kwietnia 2014), „L'Osservatore Romano", wyd. polskie, 35 (2014), nr 5, s. 37.

27 Por. AL 325.

28 Tomasz z Akwinu, Summa Theologiae II-II, q. 24, a. 7; AL 134.

29 Por. AL 136-141. 
miarach i wzajemnych odniesieniach, jednak bez dawania pierwszeństwa płciowości. Papież przyznaje, że Bóg stworzył płciowość, która jest wspaniałym darem, a św. Jan Paweł II wyjaśnił, że człowiek „jest wezwany również do pełnej i dojrzałej spontaniczności odniesień" 30 ; to jednak zachęca do sztuki przekształcenia siebie. Polega ona na uświadomieniu sobie, że zakochujemy się w całej osobie, posiadającej swoją własną tożsamość, a nie tylko w jej cielesności. Takie podejście do miłości małżeńskiej pozwala na jej rozwój nawet wówczas, gdy piękno zewnętrzne mija. Więź małżeńska i rodzinna znajduje wówczas nowe formy wyrazu i rozwoju w codzienności życia ${ }^{31}$.

Miłość zawsze obdarza życiem, dlatego miłość małżeńska nie wyczerpuje się wśród samych małżonków. Rodzina staje się środowiskiem zrodzenia jako przyjęcia daru, który pochodzi od Boga. Z kolei dziecko, które jest tym darem, owocem miłości małżonków, ma prawo do miłości rodziców, która wypływa z głębokości ich wzajemnych więzi tworzących fundament rodziny. Ukazują oni swoim dzieciom macierzyńskie i ojcowskie oblicze Pana ${ }^{32}$.

Papież zauważa, że istotne w kształtowaniu duchowości małżeńskiej i rodzinnej jest otwarcie grona rodzinnego na całość rodziny, w której są rodzice, wujowie i kuzyni. W tej dużej rodzinie znajdują się przestrzenie, w których można dzielić się miłością i służbąą3.

Papież zwraca również uwagę na chrystocentryczny wymiar duchowości rodzinnej. Zachęca do tego, by małżeństwa i rodziny umiejscowiły Chrystusa w centrum swoich wspólnot. Naucza, że „jeśli rodzinie udaje się skupić na Chrystusie, to jednoczy On i rzuca światło na całe życie rodzinne"34. Widać tutaj również wyraźny świętorodzinny rys duchowości chrześcijańskiej, w której Maryja i Józef koncentrują siebie wokół Jezusa. Duchowość ta zmierza do tworzenia wokół Jezusa jednej wspólnej rodziny ludzkiej ${ }^{35}$.

${ }^{30}$ Jan Paweł II, Katecheza (12 listopada 1980): Insegnamenti 3/2 (1980), 1133; Dzieła zebrane, t. 6, Katechezy, Kraków, 2007, s. 223; AL 150-151.

31 Por. AL 164.

32 Por. tamże, 165-166.172.

${ }^{33}$ Por. XIV Zwyczajne Zgromadzenie Ogólne Synodu Biskupów, Relacja końcowa 2015, 11; AL 187.

${ }^{34}$ AL 317.

35 Por. tamże, 325; Więcej na temat duchowości świętorodzinnej zobacz: J. Ber- 
Bliskość Jezusa w życiu małżeńskim i rodzinnym pozwala przeżyć cierpienia i problemy w jedności z Jego krzyżem. Stanowi siłę i motywację do walki o przetrwanie małżeństwa w chwilach kryzysów i wątpliwości. Uświęca życie rodzinne, przekształcając trudne doświadczenia w ofiarę miłości ${ }^{36}$. Ponadto, jak zaznacza Papież, nawiązując do adhortacji Jana Pawła II Vita Consecrata (1996), chwile radości, odpoczynku i święta są doświadczane jako udział w pełni życia zmartwychwstania Chrystusa. Małżonkowie poprzez różne codzienne gesty tworzą „przestrzeń teologalną, w której można doświadczyć mistycznej obecności zmartwychwstałego Pana" 37 .

Papież Franciszek podaje również sposoby rozwoju duchowości małżeńskiej i rodzinnej. Jako pierwszy wskazuje na modlitwę rodzinną. Ponadto zachęca do praktykowania różnych form pobożności ludowej, $\mathrm{w}$ których rodzina odnajduje swe umiejscowienie w czasie i historii. Jednakże najbardziej wzywa do udziału w niedzielnej Eucharystii, która jest sakramentem Nowego Przymierza. W nim dokonuje się odkupieńcze działanie Chrystusa (por. Łk 22,20), co pozwala dostrzec głębokie więzi między życiem małżeńskim a Eucharystią ${ }^{38}$. Pokarm Eucharystii jest siłą i inspiracją, aby przeżywać każdego dnia przymierze małżeńskie jako „Kościół domowy”39.

Ważnym elementem duchowości małżeńskiej proponowanej przez Papieża Franciszka jest wierność i odpowiedzialność za siebie. Małżonkowie podejmują wyzwanie i pragnienie, by razem się zestarzeć, odzwierciedlając $\mathrm{w}$ ten sposób wierność Boga. Ta stanowcza decyzja,

thier, Kult i naśladowanie Świętej Rodziny, tłum. A. Bocian, Pelplin 2003; A. Sobczyk, Biblijne podstawy duchowości świętorodzinnej, „Ruch Biblijny i Liturgiczny” 62 (2009) 1, s. 53-65; tenże, Główne elementy duchowości świętorodzinnej w Zgromadzeniach Świętej Rodziny w Polsce, RT, t. 55, Lublin 2008, s. 101-129; A. Sobczyk, P. Krupa, W kregu duchowości świętorodzinnej, Pelplin 2007; K. Wolski, Nazaret źródło świętości. Podstawy duchowości rodzinnej w świetle nauczania Jana Pawła II, Łomianki 2001.

36 Por. Relacja końcowa 2015, 87.

37 Jan Paweł II, Adhortacja, Vita consecrata (25 marca 1996) 42; AL 317.

${ }^{38}$ Franciszek przypomina, że przymierze Boga ze swoim ludem wyraża się jako zaręczyny (por. Ez 16,8.60; Iz 62,5; Oz 2,21-22), a Nowe Przymierze ukazane jest jako małżeństwo (por. Ap 19,7; 21,2; Ef 5,25). AL 318.

${ }^{39}$ Sobór Watykański II, Konstytucja dogmatyczna o Kościele, Lumen gentium (dalej KK) 11; AL 318. 
naznaczająca styl życia, jest „wewnętrznym wymogiem przymierza miłości małżeńskiej" ${ }^{40}$,

Wierność i odpowiedzialność małżonków staje się przestrzenią słusznej autonomii prowadzącej do wolności, kiedy każdy odkrywa, że jego druga połowa nie należy do niego, ale do Boga, który może zajmować centrum jej życia. Wymaga to wewnętrznego ogołocenia. Własna przestrzeń, jaką każdy z małżonków zastrzega dla swej osobistej relacji z Bogiem, pozwala leczyć rany wspólnego życia i odnaleźć w miłości Boga sens swego istnienia ${ }^{41}$.

W optyce skierowanej na Boga nie może jednak zabraknąć człowieka, zwłaszcza poślubionego w Bogu na zawsze. Dlatego według Franciszka Bóg wzywa małżonków do przekazywania życia i opieki, co konkretyzuje się w okazywaniu należnej uwagi wzajemnej i wsparcia. To zasadnicze elementy duchowości małżeńskiej i rodzinnej według Papieża. Boża miłość objawia się w słowach, spojrzeniach, pomocy, pieszczotach, uścisku ${ }^{42}$.

Papież wzywa także do kontemplacji współmałżonka. Stwierdza, że „podziwianie ukochanej osoby oczyma Boga i rozpoznawanie w niej Chrystusa jest głębokim doświadczeniem duchowym. Wymaga to bezinteresownej dyspozycyjności pozwalającej docenić jej godnośc”"43. Wzorem do naśladowania jest dla małżonków sam Jezus, który na każdego patrzył z miłością (por. Mk 10,21). Uważne wpatrywanie się w człowieka uzdalnia do większej troski o niego i świadomości, że jest się kochanym. Przejawia się to szczególnie w udzielaniu subtelnej pomocy w razie choroby czy pojawienia się innych ograniczeń ${ }^{44}$.

Szczególną cechą duchowości małżeńskiej i rodzinnej jest zdaniem Franciszka gościnność. Wypływa ona $\mathrm{z}$ faktu, że pod wpływem Ducha Świętego rodzina nie tylko przyjmuje życie, rodząc je w swoim łonie, ale się otwiera, wykracza poza swoje granice, aby obdarzyć swoim dobrem również innych (por. Hbr 13,2). Miłość społeczna, będąca odzwierciedleniem Trójcy Świętej, jest w istocie tym, co jednoczy duchowy sens rodziny i jej misję. Rodzina żyje specyficzną duchowością, będąc jednocześnie

\footnotetext{
40 Jan Paweł II, Adhortacja, Familiaris consortio, (dalej FC) 11; AL 319.

${ }^{41}$ Por. AL 320.

42 Por. tamże, 321.

43 Tamże, 323.

${ }^{44}$ Por. Relacja końcowa 2015, 88.
} 
Kościołem domowym i żywotną komórką społeczną, która jest zdolna zmienić świat ${ }^{45}$.

Wiele miejsca w całym swoim nauczaniu Franciszek poświęca radości. Podobnie jest i w tym dokumencie. Papież, pisząc o małżeństwie, zauważa, że powinno się dbać o radość miłości. Ona poszerza zdolność rozkoszowania się i pozwala zasmakować w różnych rzeczach, na różnych etapach życia, zarówno wtedy, kiedy jest dobrze, jak i w cierpieniu ${ }^{46}$.

\section{TOWARZYSZENIE JAKO SPOSÓB ROZWOJU DUCHOWOŚCl MAŁŻEŃSKIEJ I RODZINNEJ}

Duchowość chrześcijańska jest formą życia w Duchu Świętym, umożliwiającą i motywującą człowieka do naśladowania Chrystusa na sobie właściwej drodze życia. W przypadku małżonków określa się ona codziennym życiem w małżeństwie i rodzinie, radościami i trudnościami z tym życiem związanymi. Powoduje to sytuację, w której sami małżonkowie nie zawsze mają czas zastanowić się nad własnym życiem duchowym. Nie wszyscy też mogą uczestniczyć w różnego rodzaju rekolekcjach czy spotkaniach duszpasterskich. Wychodząc naprzeciw tym problemom, Papież zachęca w swej adhortacji do szeroko pojętego towarzyszenia małżeństwom i rodzinom. Obejmuje ono zarówno troskę o życie duchowe rodzin, jak i o wsparcie pastoralne od okresu narzeczeńskiego, poprzez początki życia w małżeństwie, pokonywanie kryzysów, aż do chwili, kiedy jedno z małżonków umiera.

\subsection{GŁOSZENIE EWANGELII RODZINY}

Pierwszym zadaniem duszpasterzy wpływającym na rozwój życia duchowego małżeństw i rodzin jest głoszenie Ewangelii rodziny. Rodziny chrześcijańskie, z uwagi na łaskę sakramentu małżeństwa, są głównymi podmiotami duszpasterstwa rodzinnego ${ }^{47}$. Ewangelia rodziny jest

${ }^{45}$ Por. FC 44; AL 324.

${ }^{46}$ Por. tamże, 126; 129-130.

${ }^{47}$ III Nadzwyczajne Zgromadzenie Ogólne Synodu Biskupów, Relacja Synodu 2014, 30, A. Sobczyk, Rodzina chrześcijańska w nauczaniu papieża Franciszka, s. 201-202. 
radością, która „napełnia serce i całe życie” ${ }^{48}$. Kościół chce dotrzeć do rodzin z pokornym zrozumieniem i swoją chęcią „towarzyszenia każdej i wszystkim rodzinom, aby odkryły najlepszy sposób przezwyciężenia trudności napotykanych na swojej drodze"49. Zdaniem Papieża w tym celu konieczny jest „wysiłek ewangelizacyjny i katechetyczny skierowany do wnętrza rodziny" 50 .

Ewangelia rodziny jest odpowiedzią na najgłębsze pragnienia człowieka: jego godności i pełnej realizacji we wzajemności, w jedności i płodności. Chodzi tutaj głównie o zaproponowanie wartości, które przyczynią się do rozwoju duchowego rodziny. W tym celu potrzebna jest właściwa formacja osób, które będą się zajmowały realizacją tego zadania ${ }^{51}$.

Głoszenie Ewangelii rodziny rozpoczyna się już w czasie prowadzenia narzeczonych na drodze przygotowania do małżeństwa. Polega na umożliwieniu młodym ludziom poznania atrakcyjności życia razem w jedności, wierności, miłosnym zjednoczeniu i służbie społeczeństwu, poprzez otwartość na dar życia i wychowywanie dzieci. Sprostanie temu zadaniu wymaga zaangażowania całej wspólnoty chrześcijańskiej, zwłaszcza gdy idzie o zwrócenie uwagi na cnotę czystości, która jest „warunkiem autentycznego rozwoju prawdziwej miłości międzyosobowej” ${ }^{52}$.

Według Papieża Franciszka wszelkie rodzaje towarzyszenia powinny przekonać narzeczonych i małżonków do rozumienia małżeństwa jako powołania, które dopiero zaczyna się realizować. Mają być przede wszystkim umacnianiem więzi między kobietą a mężczyzną, obejmować drogi duchowe, teoretyczne i wskazówki praktyczne w atmosferze miłości, która mobilizuje do wzajemnego ofiarowania się sobie przez współmałżonków. Wskazuje również ludzi i ośrodki, do których mogliby się zwrócić, dając pierwszeństwo życiu sakramentalnemu ${ }^{53}$.

${ }^{48}$ Franciszek, Adhortacja Evangelii gaudium; A. Sobczyk, Duchowość misyjna forma głoszenia Ewangelii dzisiaj, „Teologia i moralność” 15 (2014) 1, s. 264.

49 Por. Relacja końcowa 2015, 56.

50 Por. tamże, 81; AL 200.

51 Por. AL 201-203.

${ }^{52}$ Por. tamże, 205-206; Franciszek, Głoście Ewangelię, jeśli trzeba, także słowami. Spotkanie z młodzieżą na placu przed bazyliką Matki Bożej Anielskiej 4.10.2013, „L 'Osservatore Romano" wersja polska 34 (2013), nr 11 s. 17.

${ }^{53}$ Por. AL 211; FC 11,13,19; J. Misiurek, Sakramentalny wymiar miłości, 
W przygotowaniu bardziej bezpośrednim duchowości małżeńskiej służy dokładne wyjaśnienie nowożeńcom sensu każdego gestu podczas celebracji liturgicznej. Istotne jest, by narzeczeni zrozumieli znaczenie teologiczne i duchowe całej uroczystości, a zwłaszcza zgody małżeńskiej. Słowa przysięgi małżeńskiej pociągają za sobą pewną totalność, obejmującą przyszłość: „dopóki śmierć was nie rozdzieli” ${ }^{54}$.

$\mathrm{Z}$ kolei towarzyszenie $\mathrm{w}$ pierwszych latach życia małżeńskiego dotyczy $\mathrm{z}$ jednej strony uzupełnienia przez narzeczonych procesu, który powinien się dokonać $\mathrm{w}$ okresie narzeczeństwa, a z drugiej ma doprowadzić do zrozumienia, że małżeństwa nie można pojmować jako czegoś zakończonego. Zdaniem Franciszka sakramentalne małżeństwo skierowane jest ku przyszłości. Z tego względu nowożeńcom i młodym małżonkom trzeba przedstawiać ich związek od samego początku z realistyczną jasnością. Rozpoczęcie wspólnej drogi wymaga wielkodusznego daru z siebie. Papież szeroko omawia poszczególne etapy, podkreślając w nich konieczność wzajemnej miłości i jedności małżonków ${ }^{55}$.

Towarzyszenie duchowe powinno zachęcać rodziny do wzrastania w wierze, udziału w niedzielnej Eucharystii, częstej spowiedzi, kierownictwa duchowego, uczestnictwa w rekolekcjach. Zdaniem Franciszka rodzina, która razem się modli, trwa razem ${ }^{56}$. Z kolei parafie, ruchy, szkoły i inne instytucje Kościoła mogą na różne sposoby pośredniczyć w trosce i ożywianiu życia rodzin. Grupy te stanowią okazję, by dzielić się wiarą i doświadczeniem w celu umacniania małżonków i ich rozwoju ${ }^{57}$.

w: Małżeństwo - przymierze miłości, red. J. Misiurek, W. Słomka, seria „Homo meditans”, t. 15, Lublin 1995, s. 29-31; A. Sobczyk, Co może i powinien zrobić kapłan w sytuacji kryzysu małżństwa i rodziny?, „Homo Dei” 81 (2012) 1, s. 64-65.

${ }_{54}$ Por. AL 213-214.

55 Omawia etap początkowej fascynacji charakteryzującej się pożądaniem zmysłowym, następnie proces kształtowania postrzegania drugiej osoby, jako części swego życia. Kolejnym krokiem jest umiejętność cieszenia się we wzajemnej przynależności i pojmowania całego życia jako projektu obojga. Ostatecznym zaś zdolność przedkładania szczęścia drugiej osoby ponad swoje potrzeby i postrzegania swego małżeństwa jako dobra dla społeczeństwa. Por. AL 217-218, 220.

${ }^{56}$ Por. tamże, 227.

57 Obejmuje to m.in.: spotkania małżeństw z sąsiedztwa, rekolekcje dla małżonków, konferencje specjalistów dotyczące konkretnych problemów związanych z życiem rodzinnym, ośrodki poradnictwa małżeńskiego oraz szerszego poradnictwa dotyczącego 
Dobrze prowadzone duszpasterstwo służy również małżeństwom oddalonym od Boga. Pozwala, przy okazji różnych uroczystości rodzinnych (chrztu dziecka, pierwszej Komunii św., pogrzebu lub ślubu krewnego czy przyjaciela), zaproponować im ponownie, w atrakcyjny sposób, ideał małżeństwa chrześcijańskiego i zbliżyć ich do przestrzeni towarzyszenia ${ }^{58}$.

\subsection{POMOC W SYTUACJACH KRYZYSOWYCH}

Papież w swej adhortacji nie zamyka żadnej rodzinie możliwości rozwoju jej duchowości. Nawet te będące w kryzysie lub oddaleniu mogą umacniać więź z Bogiem i między sobą, tym bardziej że przezwyciężony kryzys prowadzi do udoskonalenia dojrzałości dotychczasowej relacji małżeńskiej. Nie jest dobrze, gdy małżonkowie ukrywają problemy, gdyż wówczas więź między nimi nie jest budowana na prawdzie i zaufaniu. W kryzysie, którego nie podjęto, największy uszczerbek ponosi wzajemna komunikacja ${ }^{59}$.

Wspólna rozmowa o zaistniałych trudnościach pomaga stworzyć atmosferę szczerości, zaufania i gotowości do współpracy. Pozwala również spojrzeć w serca małżonków. Papież nazywa takie trudne rozmowy „porodem", który pozwala wydobyć na zewnątrz najbardziej ukryte przyczyny różnić. Minie on i w sercach małżonków pozostawi nowy skarb. Franciszek zauważa, że istnieją powszechne kryzysy, które dotykają wszystkich małżeństw, oraz kryzysy osobiste mające wpływ na małżeństwo, związane $\mathrm{z}$ trudnościami gospodarczymi, w pracy, emocjonalnymi, społecznymi, duchowymi ${ }^{60}$.

różnych sytuacji rodzinnych (uzależnienia, zdrada, przemoc w rodzinie), miejsca rozwijania duchowości, warsztaty formacyjne dla rodziców dzieci problemowych. Istnieją również grupy wsparcia duszpasterskiego, modlitewnego, formacyjnego. AL 229.

58 Por. AL 230.

59 Por. tamże, 232-233.

${ }^{60}$ Papież wymienia m.in.: kryzys początków, polegający na wzajemnej akceptacji i odłączeniem od rodziców; kryzys związany z narodzeniem dziecka, kryzys wychowania dziecka, jego dojrzewania, a następnie kryzys „pustego gniazda”, gdy dziecko opuszcza dom rodzinny, a rodzice muszą na nowo ułożyć sobie życie we dwoje, przygotowując 
Towarzyszenie duchowe powinno pomóc małżonkom odnowić wybór drugiej osoby jako towarzysza drogi, pomimo ograniczeń, i to na całe życie. Każdy kryzys jest jakby nowym „tak”, umożliwiającym to, by miłość odradzała się umocniona, przemieniona, bardziej dojrzała. Wiele sytuacji kryzysowych wynika ze starych niezaleczonych zranień i braku poczucia miłości w dzieciństwie. Mają one wpływ na małżeństwo i życie rodzinne, gdyż nie pozwalają zaufać i ofiarować siebie drugiej osobie ${ }^{61}$.

Ważnym etapem towarzyszenia jest to następujące po rozpadzie związku i po rozwodzie. Papież dostrzega przypadki, w których separacja jest nieunikniona. Jednak zawsze uważa ją za środek ostateczny. Stwierdza, że zawsze należy pomóc osobom, które doświadczyły niesprawiedliwie separacji, rozwodu lub porzucenia. Zauważa, że są wśród nich osoby nierzadko zmuszone do ucieczki wskutek maltretowania przez współmałżonka. Potrzebują pomocy w procesie wybaczania doznanych krzywd. Z kolei osoby rozwiedzione, które nie zawarły nowego związku małżeńskiego, trzeba zachęcać do znajdywania w Eucharystii pokarmu, który wspiera je w wytrwałości w takim stanie ${ }^{62}$.

Zdaniem Ojca Świętego osoby rozwiedzione żyjące w nowych związkach powinny utrzymywać kontakt ze wspólnotą Kościoła i odczuwać, że są jej częścią. Troska o te osoby jest dla wspólnoty chrześcijańskiej wyrazem miłości. Powinna ona towarzyszyć rozwiedzionym rodzicom żyjącym w nowym związku, włączać i pomagać im w ich roli wychowawczej. Pomoc rodzicom w leczeniu ich ran i ich duchowe przyjęcie jest również ważne dla dzieci, które potrzebują rodzinnego oblicza Kościoła, otwartego dla nich w tym traumatycznym doświadczeniu ${ }^{63}$.

W rozeznaniu duszpasterskim należy „określić elementy, które mogą sprzyjać ewangelizacji oraz wzrostowi ludzkiemu i duchowemu”64. Papież zachęca, by podjąć próbę przekształcenia ich w możliwość podą-

się do wspólnej starości. AL 235-236; A. Sobczyk, Kierownictwo duchowe i poradnictwo rodzinne. Możliwości ich wspólnego zastosowania $w$ trakcie rekolekcji dla rodzin, „Teologia i moralność” 12 (2012), s. 177-186; tenże, Co może i powinien zrobić kapłan w sytuacji kryzysu małżeństwa i rodziny?, s. 64-66.

${ }^{61}$ Por. AL 238-240.

62 Por. FC 184; AL 241-242.

63 Por. AL 243; 246.

${ }^{64}$ Tamże, 293. 
żania ku pełni małżeństwa i rodziny w świetle Ewangelii. Przypomina, że św. Jan Paweł II zaproponował tak zwane „prawo stopniowości”, będąc świadomym, że człowiek „poznaje, miłuje i czyni dobro moralne, odpowiednio do etapów swego rozwoju" ${ }^{\prime 2}$.

Droga Kościoła to droga Jezusa: pełna miłosierdzia i integracji. Papież w swoim dokumencie podkreśla pragnienie włączenia wszystkich ludzi. Uważa, że należy pomóc każdemu w znalezieniu jego sposobu uczestnictwa we wspólnocie kościelnej, aby czuł się przedmiotem „niezasłużonego, bezwarunkowego i bezinteresownego" miłosierdzia ${ }^{66}$.

Wspólnota eklezjalna, zachowując i broniąc pełnego ideału małżeństwa według planu Bożego, z miłosierdziem i cierpliwością towarzyszy osobom przeżywającym trudności i kryzysy. Papież przypomina, że zadaniem Kościoła jest głoszenie miłosierdzia Boga. Jednak miłosierdzie to nie jest tylko działanie Ojca. Wszyscy ludzie zostali wezwani do życia miłosierdziem, ponieważ wpierw to oni sami doznali miłosierdzia. $\mathrm{Z}$ tego powodu wszystko $\mathrm{w}$ działaniu duszpasterskim powinno być przepojone czułością i miłosierdziem, z którą kieruje się do wiernych ${ }^{67}$.

Duchowość życia małżeńskiego i rodzinnego obejmuje również dobre przygotowanie do śmierci własnej i współmałżonka. Wymaga troskliwego i delikatnego towarzyszenia. Opiera się na wierze, że nie istnieje całkowite zniszczenie tych, którzy umierają, a jednym ze sposobów komunikowania się z bliskimi, którzy zmarli, jest modlitwa za nich. Akceptacja śmierci umożliwia właściwe do niej przygotowanie. Drogą do tego celu jest wzrastanie w miłości wobec tych, którzy podążają wraz $\mathrm{z}$ nami do życia wiecznego ${ }^{68}$.

Podsumowując, warto zauważyć, że Papież Franciszek nawiązuje do nauczania soborowego, a szczególnie do posynodalnej adhortacji Jana Pawła II Familiaris consortio (1981). Struktura dokumentu też jest podobna. Pewne novum stanowi ostatni rozdział poświęcony duchowości małżeństwa i rodziny. Osią wykładu jest miłość ujmowana jako wzajemny dar małżonków, który w ich wspólnym życiu należy nieustannie rozwijać.

\footnotetext{
${ }^{65}$ FC 123; AL 295.

66 Por. AL 296-297.

67 Por. tamże, 307, 309-310.

68 Tamże, 253-258.
} 
Papież wzywa do umacniania więzi małżeńsko-rodzinnych, a jako główną troskę duszpasterską sugeruje szeroko pojęte towarzyszenie. Obejmuje ono zarówno wymiar duchowy, jak i pastoralny, już od okresu narzeczeńskiego, pierwsze lata małżeństwa, a szczególnie, w chwilach trudności i kryzysów małżeńskich.

Streszczenie. Koncepcja duchowości małżeńskiej i rodzinnej prezentowana przez Papieża Franciszka ma silne podstawy biblijne i teologiczno-dogmatyczne. Stanowi owoc dyskusji obu synodów poświęconych rodzinie. Nawiązuje do wcześniejszego nauczania w tym temacie, szczególnie do adhortacji posynodalnej Familiaris Consortio (1981) i całego nauczania św. Jana Pawła II w zakresie wzmacniania relacji małżeńskich i przekształcania communio personarum $\mathrm{w}$ communio amoris. Jako punkt odniesienia ujmuje miłość opartą na wzajemnych relacjach małżonków i dążącą do umocnienia ich więzi. Wiele miejsca poświęca omówieniu sposobów pomocy: duchowej, sakramentalnej i pastoralnej, świadczonej narzeczonym i małżonkom. Adhortacja stanowi najnowsze pogłębione i poszerzone spojrzenie Kościoła na małżeństwo i rodzinę.

Słowa kluczowe: Amoris Laetitia; duchowość; małżeństwo; rodzina.

Abstract. The concept of the spirituality of marriage and the family in the light of the Exhortation Amoris Laetitia. To sum up it is worthwhile that the Pope Francis refers to the Council's teaching and especially to the Post-Synodal Exhortation of Pope John Paul II, Familiaris Consortio (1981). The structure of the document is also similar. Some novelty is constitutes the last chapter devoted to the spirituality of marriage and family. The axis of the lecture is love recognized as a reciprocal gift of the spouses, who in their common life should continually develop. The Pope calls for strengthening the relationship of marital- family, and as the main pastoral care I am suggesting widely comprehended accompaniment. It covers both spiritual as well as pastoral dimension, already from the engagement period, the first years of marriage, especially in times of difficulty and crisis of marriage.

Keywords: Amoris Laetitia; spirituality; marriage; family. 